\title{
Demographic Variables and Stress Management Among Cataloguers in University Libraries in Cross Rivers State
}

\author{
Dr. Boma T. David-West. CLN \\ Department of Library and Information Science University of Port Harcourt, Rivers State, Nigeria
}

Mrs Eseme A. Jonah, CLN.

Akwa- Ibom State Polytechnic Library

\begin{abstract}
This study investigated demographic variables and stress management among cataloguers in university libraries in Cross Rivers State. It was undertaken as a descriptive survey research design. The population of the study was 25 professional and para-professional librarians (i.e. $\mathrm{UNICAL}=12$, CRUTECH 9 and A.T.U $=4$ ). The sample size was also 25 using the census sampling technique. The researcher used the whole population as sample because, it was small. The instrument titled "Demographic Variables and Stress Management among Cataloguers Questionnaire (DVSMCQ) was used to elicit information from the respondents. The instrument was validated by experts in the field of study. Reliability test was by test- retest method using Pearson Product Moment Correlation Coefficient ( $\mathrm{r}$ ) which yielded reliability coefficient of 0.78 meaning that, the instrument was reliable, consistent and good for this study. Mean and standard deviation was used to answer the research questions while the t-test was used to test the hypotheses. The findings revealed that there is a significant difference between the independent variable (age, gender, marital status and academic qualification) and dependent variable (stress management) among cataloguers. In conclusion, females are more stressed in the job when compared with their male counterparts. It was recommended among others that cataloguers should develop positive job attitude to work and not wait until accreditation, before doing their job in order to avoid stress.
\end{abstract}

Keywords: Demographic, Variables, Stress Management, Cataloguers, Libraries

DOI: $10.7176 / \mathrm{IKM} / 9-9-01$

Publication date:October $31^{\text {st }} 2019$

\section{Introduction}

Demographic variables are gradually becoming important factors in stress management of cataloguers in Academic Libraries. Stress management is a problem in the library organization, just as in other businesses. Well and Hogan (2016) indicates that the vast majority of employee experience high level of stress in their work places, which can generate negative impact on both the employee and the organization. Therefore it is important to identify and understand the stress experienced by employees in order to develop appropriate management methods.

The presence of stress at work is almost inevitable in all organizations but to manage it in a right way is so important for all libraries. Wong and Huang (2014) states that encouraging employees to develop selfmechanisms to handle stress is important. In libraries the management should identify and manage the factors of employee comfort and satisfaction, so as to increase their performance. Stress can include environment, health, financial, psychological or family issues. (Rajasekar 2013). To control stress, librarians usually should begin by understanding job stress as a concept that should be managed.

Bamber (2011) observed that excessive job demands can result in excessive stress. Individuals should try to reduce the discomfort associated with stress to its barest minimum in order to have maximum output. The effect stress have on cataloguers as well as the institution demand that strategies be put in place towards duties of processing and organizing materials for accessibility to the users community. Despite the emergence of ICT in university libraries, the University of Calabar and Cross Rivers State University of Science and Technology is still engaging in the manual cataloguing. These activities no doubt places high demand on cataloguing, thus resulting in stress.

Stress at work, can affect an organization with employee absenteeism, intention to leave the job, interpersonal difficulties and poor performance (Asthon, 2017). That is to say stress at work will definitely affect an organization negatively by losing manpower hours. Cataloguers can only overcome stress when they acknowledge it than experience the effects.

Ajalla (2011) opined that the best approach to manage work place stress in the library is changing one's perception about the profession and its stress area. Cataloguers should also take out time to relax when they notice stressful conditions.

In order to achieve good performance and applicable level of productivity, work environment must be devoid of stress in any form. It is useful to involve staff in consultation process and explain changes on employee job and communicate to them strategies on how to manage the change. The relevance of library 
achievement personnel to the achievement of library's goals and objectives cannot be over emphasized. Thus this study investigates demographic variables and stress management among cataloguers in university libraries in Cross Rivers State.

\subsection{Statement of the Problem}

Demographic variables and stress management are vital to organizational output. It has been observed by researchers that productivity in libraries are declining due to stress. Demographic variables that have been identified to influence stress are age, gender, marital status and academic qualification. All these have effect on the productivity output of the library. Despite the effort of library management to motivate staff to perform better. Many cataloguers remain uncommitted until Nigerian Universities Commission (NUC) are coming for accreditation that is when most cataloguers process their materials. These however makes the work very stressful for the cataloguers. Thus the researcher's quest to find out the cause of low productivity. The study therefore focus on demographic variables and stress management among cataloguers in university libraries in Cross Rivers State.

\subsection{Objective of the Study}

1. To examine age and stress management among cataloguers in university libraries in Cross Rivers State.

2. To determine marital status and stress management among cataloguers in university libraries in Cross Rivers State.

3. To ascertain gender and stress management among cataloguers in university libraries in Cross Rivers State.

4. To determine academic qualification and stress management among cataloguers in university libraries in Cross Rivers State.

\subsection{Research Questions}

1. How does age affect stress management among cataloguers in university libraries in Cross Rivers State?

2. How does gender influence stress management among cataloguers in university libraries in Cross Rivers State?

3. To what extent does marital status influence stress management among cataloguers in university libraries in Cross Rivers State?

4. How does academic qualification affect stress management among cataloguers in university libraries in Cross Rivers State?

\subsection{Hypothesis}

1. There is no significant difference between age and stress management among cataloguers in university libraries in Cross Rivers State.

2. There is no significant difference between gender and stress management among cataloguers in university libraries in Cross Rivers State.

3. There is no significant difference between marital status and stress management among cataloguers in university libraries in Cross Rivers State.

4. There is no significant difference between academic qualification and stress management among cataloguers in Cross Rivers State.

\section{Literature Review}

Cataloguing is labour intensive and involves frequent notations, work overload and anti-social working hours and highly emotional labour characteristics (Mansour 2017). Therefore, even if the presence of stress at work is almost inevitable in all organizations, to manage it in the right way is very important for all libraries like other organizations. To control stress the organization usually begin by understanding job stress as a concept, with reasons and results. Job satisfaction positively correlates with employee performance productivity (Chiang and Liu 2017).

Marital status is a demographic variable associated with stress management. This concern is critical since stress management may have different level of impact between married and unmarried employees. Iravania, et al., (2012) observed that married employees are more stressed as compared to unmarried colleagues. In specific terms, he concluded that married female employees experience more stress than married males. Nagariju and Nandini (2013) asserted that there are significant differences between insurance employee's marital status and occupational stress. They concluded that working married women experience more stress than their counterparts.

Stress is anything that changes one's physical, emotional, behavioural or mental state while the individual encounters various stimuli in their environment (Igbal and Kokash). Employee's family responsibilities outside library could be one of the stressors. Okonkwo (2014) stated that family stress interferences with work result in 
family conflicts which in turn results to pressure tension, anxiety, stress to the employee married women experience a considerable, amount of stress. Anju (2015) observed that there is statistically no difference between married and unmarried employees.

Gender, for males, work stress is more strongly related to concerns about their roles. In the power structure of an organization, whereas female employees reported experience more several stress when there is conflict between job requirement and family relationships.

Kim (2014) carried out a study between demographic factors and stress factors were examined. It was said that up to one third of the respondent reported significant levels of stress, which vary by age and gender. The result of the analyses showed that gender varied. This indicates that male respondents indicated more stress related to organizational processes such as performance, committing mistakes and job security while female recorded higher frequencies for stress relating to role characteristics such as conflicting duties, lack of assistance and confusion with service.

A study by Agyemany and Arkorful (2013) also emphasized that in terms of gender, male and female did not differ with respect to job stress. The results from the studies show that female placed more emphasis on some of the afore mentioned stress factors than male. Klassen and Chu (2010) found that female teachers experience greater stress from work load and student behaviour in classroom management. O'Neil and Davis (2011) said that there are no significant differences by gender.

Age and stress management Poctnet et al., (2015) in their study of migrant employees, discussed the relationship between different age groups and job stress. They said that 18-29 age group in particular showed a higher level of job stress than the older employees.

Also Matt and Dean 1993, found that the effect of distress was twice as great in a sample of older persons than sample of younger persons. Law et al (1995) stated that there was no significant difference between the sources of stress and the age respondents.

Stress levels are higher among those who are less educated (Tsutsumi et al., (2001). On their part, Jones and Bright (2001) found out that men with higher education were more likely to express reactions to environmental stressors in psychological terms than those with lower education. A research conducted on stress management, education and work ability of nurses indicated that nurses with low education were perceived to experience stress compared to their counterparts with higher education (Golubic, et al., 2009).

Hunnur and Bagali (2014) revealed that stress causing dimensions did not differ drastically between higher and lower level. De Smet et al., (2005) found a lower prevalence of stress in more educated employee of both genders. However encouraging employees to develop self-mechanisms to handle stress is very important.

The demographic variables that have been identified, however revealed they all have effect on the productivity level of the organization.

\section{Methodology}

Descriptive survey research design was adopted for the study. The population of the study consist of all cataloguers from the three sampled universities - University of Calabar, Cross Rivers State University of Science and Technology and Arthur Javis University. The study employed census sampling technique to sample the entire population. This was done because of relatively small number of cataloguers from the sampled universities. Thus, 25 professional librarians who are cataloguers were sampled (Table 1). A self-structured questionnaire tagged Demographic Variables and Stress Management among Cataloguers Questionnaire (DVSMCQ) was utilised for the study. The instrument adopted the Likert four-point scale style and contained 20 items structured into three sub-scales namely section A, B, and C. Section A seeks for the biodata of respondents, Section B seeks for Demographic Variables, and Section C hinges on Stress Management. The instrument was vetted by test experts and using Pearson Product Moment formula, the internal consistency (reliability) obtained at $r=0.78$, which made the instrument valid for the study. 25 copies of the questionnaire were shared to the respondents and 25 copies were also retrieved as correctly responded to, making $100 \%$ response rate for the study. The research questions were answered using mean score and standard deviation, and the hypothesis tested using the statistical tool of independent t-test.

Table 1. Population and sample of the study

\begin{tabular}{l|llcccc}
\hline SN & \multicolumn{1}{|c}{ Institution } & & Population & Sample & Response & Percentage \\
\hline 1 & University of Calabar & & 12 & 12 & 12 & 48 \\
2 & $\begin{array}{l}\text { Cross Rivers State University of Science and } \\
\text { Technology }\end{array}$ & 9 & 9 & 9 & 36 \\
3 & $\begin{array}{l}\text { Arthur Javis University } \\
\text { Total }\end{array}$ & & 4 & 4 & 4 & 16 \\
\hline
\end{tabular}




\section{Results}

4.1 Research Question

Research Question One: How does age affect stress management among cataloguers in university libraries in Cross Rivers State?

Table 2. Mean scores of respondents on the ways age affects stress management among cataloguers in the university libraries in Cross Rivers State.

\begin{tabular}{|c|c|c|c|c|c|c|c|c|}
\hline \multirow[t]{2}{*}{$\mathrm{S} / \mathrm{No}$} & \multirow[t]{2}{*}{ Items } & \multicolumn{2}{|c|}{ Age } & \multicolumn{2}{|c|}{$\begin{array}{c}\text { Stress } \\
\text { Management }\end{array}$} & \multirow[t]{2}{*}{ Mean set } & \multirow[t]{2}{*}{ Rank Order } & \multirow[t]{2}{*}{ Decision } \\
\hline & & $\mathrm{X}$ & STD & $\mathrm{X}$ & STD & & & \\
\hline 1. & $\begin{array}{l}\text { Age } 16-25 \text { are likely } \\
\text { stressed in the job }\end{array}$ & 3.09 & 0.52 & 3.03 & 0.36 & 3.06 & $4^{\text {th }}$ & Agreed \\
\hline 2. & $\begin{array}{l}\text { Age } 26-35 \text { are fairly } \\
\text { stressed in the job }\end{array}$ & 3.14 & 0.56 & 3.08 & 0.36 & 3.11 & $3^{\text {rd }}$ & Agreed \\
\hline 3. & $\begin{array}{l}\text { Age } 36-5 \text { are greatly } \\
\text { stressed in the job }\end{array}$ & 3.22 & 0.55 & 3.17 & 0.35 & 3.19 & $1^{\text {st }}$ & Agreed \\
\hline 4. & $\begin{array}{l}\text { Age } 46-55 \text { are less } \\
\text { stressed in the job }\end{array}$ & 3.26 & 0.55 & 2.99 & 0.36 & 3.12 & $2^{\text {nd }}$ & Agreed \\
\hline \multirow[t]{2}{*}{5.} & $\begin{array}{l}\text { Age } 56-65 \text { are less } \\
\text { stressed in the job }\end{array}$ & 3.07 & 0.57 & 3.01 & 0.36 & 3.04 & $5^{\text {th }}$ & Agreed \\
\hline & Average mean & 3.16 & 0.55 & 3.06 & 0.35 & \multicolumn{2}{|c|}{$3.10 \geq 2.50$} & Significant \\
\hline
\end{tabular}

Data on Table 2 described the mean scores and standard deviation on the ways age affects stress management among cataloguers in university libraries in Cross Rivers State. The respondents agreed on all the items in the table with high mean scores greater than the mean criterion of 2.50 following the rank order from $1^{\text {st }}$ to $5^{\text {th }}$. The aggregate mean score of 3.10 explained that age influences stress management among cataloguers in university libraries. Since ages $16-25,26-35,36-45,46-55$ are more stressed in the job than age $56-65$ who are less stressed.

Research Question Two: How does gender influence stress management among cataloguers in university libraries in Cross Rivers State?

Table 3. Mean scores on how gender influence stress management among cataloguers in university libraries in Cross Rivers State.

\begin{tabular}{|c|c|c|c|c|c|c|c|c|}
\hline \multirow[t]{2}{*}{$\mathrm{S} / \mathrm{No}$} & \multirow[t]{2}{*}{ Items } & \multicolumn{2}{|c|}{ Gender } & \multicolumn{2}{|c|}{$\begin{array}{c}\text { Stress } \\
\text { Management }\end{array}$} & \multirow[t]{2}{*}{ Mean Set } & \multirow[t]{2}{*}{ Rank Order } & \multirow[t]{2}{*}{ Decision } \\
\hline & & $\mathrm{X}$ & STD & $\mathrm{X}$ & STD & & & \\
\hline 6. & $\begin{array}{l}\text { Males are stressed in } \\
\text { the job }\end{array}$ & 2.19 & 0.65 & 1.99 & 0.49 & 2.00 & $5^{\text {th }}$ & Disagreed \\
\hline 7. & $\begin{array}{l}\text { Females are more } \\
\text { stress in the job }\end{array}$ & 3.19 & 0.56 & 3.15 & 0.35 & 3.17 & $2^{\text {nd }}$ & Agreed \\
\hline 8. & $\begin{array}{l}\text { Males are less stress in } \\
\text { the job }\end{array}$ & 3.12 & 0.57 & 3.18 & 0.35 & 3.15 & $3 \mathrm{rd}$ & Agreed \\
\hline 9. & $\begin{array}{l}\text { Females are more } \\
\text { stressed than males in } \\
\text { the job }\end{array}$ & 3.36 & 0.53 & 3.32 & 0.31 & 3.34 & $1 \mathrm{st}$ & Agreed \\
\hline 10. & $\begin{array}{l}\text { Males are less stress in } \\
\text { the job }\end{array}$ & 3.09 & 0.57 & 3.01 & 0.37 & 3.05 & $4^{\text {th }}$ & Agreed \\
\hline & Average Mean & 2.99 & 0.57 & 2.93 & 0.37 & 2.9 & 2.50 & Significant \\
\hline
\end{tabular}

Data on table 2 presents the mean and standard deviation on the ways gender influence stress management among cataloguers in university libraries in Cross Rivers State. The respondents agreed on items 7 to 10 in the table with high mean scores greater than the mean criterion of 2.50 following the rank order from $1^{\text {st }}$ to $4^{\text {th }}$ and disagreed on item 6 with low mean score of 2.09. The aggregate mean score of 2.96 explained that females are more stressed than their male counterparts in the job. 
Research Question Three: How does marital status influence stress management among cataloguers in university libraries in Cross Rivers State?

Table 4. Mean scores of respondents on the influence of marital status on stress management among cataloguers in university libraries in Cross Rivers State.

\begin{tabular}{|c|c|c|c|c|c|c|c|c|}
\hline \multirow[t]{2}{*}{$\mathrm{S} / \mathrm{No}$} & \multirow[t]{2}{*}{ Questionnaire Items } & \multicolumn{2}{|c|}{ Marital Status } & \multicolumn{2}{|c|}{$\begin{array}{c}\text { Stress } \\
\text { Management }\end{array}$} & \multirow[t]{2}{*}{ Mean Set } & \multirow[t]{2}{*}{ Rank Order } & \multirow[t]{2}{*}{ Decision } \\
\hline & & $\mathrm{X}$ & STD & $\mathrm{X}$ & STD & & & \\
\hline 11. & $\begin{array}{l}\text { Singles are less } \\
\text { stressed in the job }\end{array}$ & 3.27 & 0.55 & 3.25 & 0.34 & 3.26 & $1^{\text {st }}$ & Agreed \\
\hline 12. & $\begin{array}{l}\text { Married are more } \\
\text { stressed in the job }\end{array}$ & 3.03 & 0.57 & 3.01 & 0.37 & 3.02 & 4th & Agreed \\
\hline 13. & $\begin{array}{l}\text { Singles are less } \\
\text { stressed than the } \\
\text { married in the job }\end{array}$ & 3.15 & 0.56 & 3.19 & 0.34 & 3.17 & $2^{\text {nd }}$ & Agreed \\
\hline 14. & $\begin{array}{llr}\text { Married are more } \\
\text { stressed } \\
\text { singles }\end{array}$ & 3.12 & 0.57 & 3.08 & 0.36 & 3.10 & $3^{\text {rd }}$ & Agreed \\
\hline 15. & $\begin{array}{l}\text { Singles are more } \\
\text { stressed than the } \\
\text { married in the job } \\
\text { Average Mean }\end{array}$ & 2.22 & 0.56 & 2.28 & 0.31 & 2.25 & $\geq 2.50$ & Disagreed \\
\hline
\end{tabular}

Data on Table 4 explains the mean and standard deviation on the ways marital status influence stress management among cataloguers in university libraries in Cross Rivers State. The respondents agreed on item 11 to 14 in the table with high mean scores greater than the mean criterion of 2.50 following the rank order from $1^{\text {st }}$ to $4^{\text {th }}$ and disagreed on item 15 with low mean score of 2.25 . The aggregate mean score of 2.96 indicates that married staff are more stressed in the job than the singles.

Research Question Four: How does academic qualification affect stress management among cataloguers in university libraries in Cross Rivers State?

Table 5. Mean scores of respondents on the way academic qualification affect stress management among cataloguers in university libraries in Cross Rivers State.

\begin{tabular}{|c|c|c|c|c|c|c|c|c|}
\hline \multirow[t]{2}{*}{$\mathrm{S} / \mathrm{No}$} & \multirow[t]{2}{*}{ Questionnaire Items } & \multicolumn{2}{|c|}{$\begin{array}{c}\text { Academic } \\
\text { Qualification }\end{array}$} & \multicolumn{2}{|c|}{$\begin{array}{c}\text { Stress } \\
\text { Management }\end{array}$} & \multirow[t]{2}{*}{ Mean Set } & \multirow[t]{2}{*}{ Rank Order } & \multirow[t]{2}{*}{ Decision } \\
\hline & & $\mathrm{X}$ & STD & $\mathrm{X}$ & STD & & & \\
\hline 16. & $\begin{array}{l}\text { Staff with Ph.D degree } \\
\text { are less stressed than } \\
\text { holders of OND, B.Sc } \\
\text { and Masters }\end{array}$ & 3.26 & 0.55 & 3.20 & 0.34 & 3.23 & $1^{\text {st }}$ & Agreed \\
\hline 17. & $\begin{array}{l}\text { Holders of OND are } \\
\text { more stressed in the } \\
\text { job }\end{array}$ & 3.07 & 0.57 & 3.11 & 0.36 & 3.09 & $4^{\text {th }}$ & Agreed \\
\hline 18. & $\begin{array}{l}\text { Holders of OND are } \\
\text { less stressed in the job }\end{array}$ & 2.29 & 0.66 & 1.97 & 0.48 & 2.05 & $5^{\text {th }}$ & Disagreed \\
\hline 19. & $\begin{array}{l}\text { Holders of OND, B.SC } \\
\text { and masters are fairly } \\
\text { stressed compared to } \\
\text { Ph.D holders }\end{array}$ & 3.19 & 0.56 & 3.15 & 0.35 & 3.17 & $2^{\text {nd }}$ & Agreed \\
\hline \multirow[t]{2}{*}{20.} & $\begin{array}{l}\text { OND, B.SC are more } \\
\text { stressed than holders } \\
\text { of Masters and Ph.D }\end{array}$ & 3.12 & 0.57 & 3.18 & 0.35 & 3.15 & $3^{\text {rd }}$ & Agreed \\
\hline & Average Mean & 2.98 & 0.58 & 2.92 & 0.37 & \multicolumn{2}{|c|}{$2.94 \geq 2.50$} & Significant \\
\hline
\end{tabular}

Data on table 4 describes the mean scores and standard deviation of the ways academic qualification influences stress management among cataloguers in university libraries in Cross Rivers State. The respondents agreed on items 16, 17, 19 and 20 in the table with high mean scores greater than the mean criterion of 2.50 following the rank order from $1^{\text {st }}$ to $4^{\text {th }}$ and disagreed on item 18 with low mean scores of 2.05 . The aggregate mean score of 2.94 explained that holders of OND and B.Sc are more stressed than holders of Masters and Ph.D. degrees in the job. This means that lower cadre in the job are more stressed when compared with the higher cadre. 


\subsection{Test of Hypotheses}

$\mathrm{H} 0_{1}$ : There is no significant difference between age and stress management among cataloguers in university libraries in Cross Rivers State.

. Table 6. t-test computation on the variables under study

\begin{tabular}{lccccccc}
\multicolumn{1}{c}{ Variables } & $\mathrm{X}$ & ST.D & Df & P & t-cal & t-crit & Decision \\
\hline Age & 3.10 & 0.36 & & & & & \\
Stress & 3.50 & 0.34 & 23 & 0.05 & 2.09 & \pm 1.96 & Significant \\
Management & & & & & & & \\
\hline
\end{tabular}

Table 6 shows the t-test computation on the difference between age and stress management among cataloguers in university libraries in Cross Rivers State, with 2.09 as the t-calculated value which is greater than the t-critical value of \pm 1.96 at 0.05 significant level. Thus reveals that the null hypothesis is rejected affirming that there is significant difference between the under studied variables (age and stress management).

$\mathrm{HO}_{2}$ : There is no significant difference between gender and stress management among cataloguers in university libraries in Cross Rivers State.

Table 7. t-test computer on the variable under study

\begin{tabular}{lccccccc}
\hline \multicolumn{1}{c}{ Variables } & $\boldsymbol{X}$ & ST.D & Df & P & t-cal & t-crit & Decision \\
\hline Gender & 2.96 & 0.34 & & & & & \\
Stress & 3.50 & 0.37 & 23 & 0.05 & 2.38 & \pm 1.96 & Significant \\
Management & & & & & & &
\end{tabular}

Table 7 presents the t-test computation on the difference between gender and stress management among cataloguers in university libraries in Cross Rivers State, with 2.38 as the t-calculated value which is greater than the $\mathrm{t}$-critical value of \pm 1.96 at 0.05 significant level. This means that the null hypothesis is rejected showing the result as significant.

$\mathrm{HO}_{3}$ : There is no significant difference between marital status and stress management among cataloguers in university libraries in Cross Rivers State.

Table 8. t-test computation on the variable under study.

\begin{tabular}{lccccccc}
\hline \multicolumn{1}{c}{ Variables } & $\mathrm{X}$ & ST.D & Df & P & t-cal & t-crit & Decision \\
\hline Marital Status & 2.96 & 0.34 & & & & & \\
Stress & 3.50 & 0.37 & 23 & 0.05 & 2.38 & \pm 1.96 & Significant
\end{tabular}

Management

Table 8 x-rayed the t-test computation on the difference between marital status and stress management among cataloguers in university libraries in Cross Rivers State with 2.38 as the t-calculated value which is greater than the t-critical value of \pm 1.96 at 0.05 significant level. This indicates that the null hypothesis is rejected meaning that, there is significant difference between the understudied variables (marital status and stress management).

$\mathrm{HO}_{4}$ : There is no significant difference between academic qualification and stress management among cataloguers in university libraries in Cross Rivers State.

Table 9. t-test computation on the variable under study.

\begin{tabular}{|c|c|c|c|c|c|c|c|}
\hline Variables & $\mathrm{X}$ & ST.D & Df & $\mathrm{P}$ & t-cal & $\mathrm{t}$-crit & Decision \\
\hline $\begin{array}{l}\text { Academic } \\
\text { qualification }\end{array}$ & 2.94 & 0.35 & 23 & 0.05 & 2.26 & \pm 1.96 & Significant \\
\hline Stress & 3.50 & 0.37 & & & & & \\
\hline
\end{tabular}

Management

Table 9 presented the t-test computation on the difference between academic qualification and stress management among cataloguers in university libraries in Cross Rivers State, with 2.26 as the t-calculated value which is greater than the $\mathrm{t}$-critical value of \pm 1.96 at 0.05 significant level. This explained that the null hypothesis is rejected indicating that there is significant difference between the understudied variables (academic qualification and stress management).

\section{Discussion}

The finding revealed that age influence stress management among cataloguers in university libraries. As shown in table 2, ages 16-25, 26-35, 36-45, 46-55 are more stressed in the job than ages 56-65 who are less stressed. The test of hypothesis one shows that, there is a significant difference between age and stress management among cataloguers in university libraries. In line with the findings, Baytar (2010) posits a relationship between age and stress factors related to organizational structure and management, such as responsibilities with roles and their density, imbalance between responsibility and authority. Pocnet et al., (2015) supports this assertion revealing that 18-29 age group in particular have a higher level of job stress than the one for older employees. Several authors affirmed that stress dimensions did differ significantly by age as the older employees are mostly 
using brain work against the younger ones who uses both brain work and physical body to accomplish a given task (Hunnur and Bagali, 2014 and Ross 2000). Pallensen (2007) stated in her study on "work-related stress and health among employees in Maimo Sweden", that there were significant difference among age groups perception of work related stress. The scholar argued that work-related stress is twice higher in younger age than in old age persons. The possible explanation to this trend is that age 18-29 are likely to be new intake and as such might be overwhelmed with the demands of the job.

Again, findings reveals that gender influence stress management among cataloguers in university libraries in Cross Rivers State. Table 3 shows that females are more stressed than their male counterparts in the job. The test of hypothesis two also indicates that there is significant difference between gender and stress management among cataloguers in university libraries. This findings synchronizes with the findings of Bright (2001) and Nelson and Burke (2002) asserting that females are more prone to work related stress than men. The scholars maintained that women are more vulnerable to the demands of work to the extent that they often have more work demands than men. Law (2004) supports this finding by stating that females recorded higher frequencies for stress relating to role characteristics such as conflicting duties, lack of assistance, confusion with the services, compared with their male counterparts. A study by Agyemang and Arkorful (2013) also emphasized that in terms of gender, females did differ with respect to job stress, contending that female employees are more stressed in the job than the males. Job stress is slightly higher among women than men.

Also, the findings shows that marital status influence stress management among cataloguers in university libraries in Cross Rivers State. Data shown in table 4 indicates that married staff are more stressed in the job than the singles. The test of hypothesis 3 reveals that there is a significant difference between the understudied variables (marital status and stress management). In line with this findings, Vanagas et al (2004) confirms that married employees, especially the females were susceptible to work-related stress than unmarried employees. This has even been found to be true in the insurance industry. Nagaraju and Nandini (2013) affirms that there are significant differences between insurance employees marital status and occupational stress. The scholars concluded that working married women experience more stress than their unmarried counterparts. Anjui (2015), Okeke (2013), Iravania et al (2012), Salawu (2004) and Faskin (2002) observed significant difference in the occupational stress among married and single women.

Finally, the findings revealed that academic qualification influence stress management among cataloguers in university libraries in Cross Rivers State. Data X-rayed in table 5 shows that holders of OND and B.Sc are more stressed than holders of Masters and Ph.D degrees in the work place. This means that the lower cadre in the job are more stressed when compared with the higher cadre. The test of hypothesis 4 indicates that there is a significant difference between academic qualification and stress management among cataloguers in university libraries in Cross Rivers State. Supporting this findings, Alexandros-Stamatios et al (2003) affirms that junior officers suffer higher stress than senior officers and junior officers experience lower job satisfaction than senior officers. The scholars maintained that this is so since the junior officers by academic qualification usually have to take and act on instructions and directive (some of which are conflicting roles) from their superior by virtue of academic qualification. This is consistent with the findings of Tsutsumi et al (2001) who asserts that workrelated stress is higher among the less educated. Jones and Bright (2001) agrees that employees with lower education were more likely to express reactions to environmental stressors in psychological terms than those with high education.

\section{Conclusion}

Libraries are constantly re-examining ways to ensure production processes with the view, to achieve greater results, especially during accreditation exercises. In the midst of these cataloguers face an increasing work load due to greater demand from the university. They are given less time for them to organize and process the information resources in order to meet up with the accreditation exercise. However, they have less staff to accomplish this project which makes it very stressful for the cataloguers. Stress if not well managed will result in cataloguer's ill health, which will manifest in low productivity. It is necessary that stress is reduced to the barest minimum in the processing unit of the library.

\section{Recommendation}

1. Cataloguers should develop positive job attitude to work and not wait until accreditation, before doing their job in order to avoid stress.

2. Government should employ more professional librarians so as to reduce the work load for cataloguers.

3. A healthy work environment should be created for the cataloguers in order to have greater output.

4. Cataloguers should learn strategies on how to manage stress in order to avoid health hazards.

\section{References}

Agyemang, C.B and Akorful, H. (2013). Influence of demographic factors on job stress and job Satisfaction 
among custom officials in Ghana. Research in Humanity and Social Science, 3(16), 37-45.

Ajalla, E.B (2011). Work related stress among libraries and information professionals in Nigerian University. Library Philosophy and Practice. http://digitalcommonsunl.edud/libphilprac Retrieved 1st May, 2019.

Alexandros-Stamatios, G.A. Matilyn, J.D. and Cary, L.C. (2003). Occupational stress, job satisfaction, and health state in male and female junior hospital doctors in Greece. Journal of Managerial Psychology, 18(6), $592-621$.

Anju, S. (2015). Managing job stress. Journal of Human Resources Review, 25(1), 40-50.

Asthon, A.S. (2017). How human resources management best practice influence employee satisfaction and job retention in the Hotel Industry. Journal of Human Resources in Hospitality and Tourism,

Bagali, R.N. (2014). Job stress, job performance and social support among hospital nurses. Journals of Nursing Scholarship, 36(91), 73-78.

Bamber, M.R. (2011). Overcoming your work place stress. A CBT based self-help guide. London; Routledge.

Baytar, O. (2010). Work stressors and co-worker support as predicators of individual strain and job performance. Journal of Organizational Behaviour, 21(4), 391 -403.

Bright, J. (2001). Individual Difference Factors and Stress: A Case Study Paper, Wales; University of New South Wales.

Chiang, C.F and Liu, B.Z. (2017). Examining job stress and burnout of hotel room attendants: international marketing and organizational commitment as moderators. Journal of Human Resources in Hospitality and Tourism, 16(4), 367-383.

De Smet, P. Sans, S. Dramaix, M. Boulenguez, C. De Backer, G. Ferrario, M. Kornitzer, M. (2005). Gender and regional differences in perceived job stress across Europe. The European Journal of Public Health, 15(5), $536-545$

Golubic, R. Milosevic, M. Knezevic, B. and Musta, Begovic, J. (2009). Work related stress education and work ability among hospital nurse. $J$ Adv Nurs. 65 (10) 2056-2066

Hunnur, S.R.R, and Bagali, M. M. (2014). A Study on relationship between occupation stress index dimensions and demographic variables of Police Sub-Inspectors and Assistant Sub-inspectors in Police Department. Psychology, 13(3), 283-284.

Igbal, A. and Kokash, H. (2011). Faculty perception of stress and coping strategies in Saudi Private University: An exploratory study. International Education Studies, 4(3), 137- 149.

Iravania, M.R., Iravania, G. Iravani, A. Mahmoudid, B. and Salimid, F. (2012). A social work study on measuring the impact of gender and marital status on stress: A case study of hydro-power employee's. Management Science Letters, 2, 2097-2102.

Jones, F and Bright, J. (2001). Stress, myth theory and research, Harlow England; Prentice Hall.

Kim, D.H., Lee Y.H. and Lee, J.W. (2014). Assessment of job stress factors and Organizational personality types for procedure based jobs in nuclear power plants. Journal of Nuclear Science and Technology 45(8), 784 792.

Klassen, R. M. and Chun, M. (2010). Effects on teachers self-efficacy and job satisfaction: Teacher's gender, years of experience and job stress. Journal of Educational Psychology 102(3), 741.

Law, J. Pearle, P.L and Woods, B.A. (2004). Stress and coping in tourist attraction employees, Tourism Management, 16(4), 277-284.

Mansour,S. and Mohanna, D. (2017). Meditating role of job stress between work, family conflict, work leisure conflict and employee perception of service quality in the hotel Industry in France Journal of Human Resources in Hospitality and Tourism, 1(21), 1-5.

Matt, G.E. and Dean, A. (1993). Social support from friends and psychological distress among elderly persons: Moderator effects of age. Journal of Health and Social Behaviour, 34, 187-200.

Nagaru, B. and Nandini, H.P. (2013). A factor of marital status highly influencing on stress of women employee's: A case study at insurance sector. International Journal of Business and Management Invention 2(10), 39-46.

Nelson, D.L and Burke, R. J. (2002). Gender, work stress and health, American Psychological Association, Washington, D.C.

Okeke, C.T.O. and Diamani, C.C. (2013). Empirical study of stressors that impinge on teachers in secondary schools in Switzerland South African Journal of Education, 33(1) 1-12.

Okonkwo, E. (2014). Female nurses experiencing family strain interference with work. Spousal support and number of children impact gender and behaviour. 12(1), 6182-6188.

Oneil, J.W. and Davis, K. (2011). Work Stress and well-being in the hotel industry. International Journal of Hospitality and Tourism 30(2), $385-390$.

Pallensen, S.C. (2007). Work related stress and health among hotel employee's in Macmo Available at http://eprints.bibi.hrk.se/archive/00001588/01/exarb_storm pallasen. Retrieved 13 ${ }^{\text {th }}$ March, 2019.

Pocnet, Antonietti, J.P., Massoudi, K, Gyorkos, C. Becker, J., De Bruin,G.P. and Rossier, J. (2015). Influence of 
individual characteristics on work engagement and job stress in a sample of national and foreign workers in Switzerland. Swiss Journal of Psychology, 5 (1)

Ross, G. F. (2000). Career stress responses among hospitality employees. Annals of Tourism Research, 24(1), 41-51.

Salawu, O.M. (2004). The impact of some demographic variables on job Stress. American Psychological Association, Washington D.C.

Tsutsumi, A. Kayaba, K, Tsutsumi, K and Ignaish, M. (2001). Association between job strain and prevalence of hypertension. A cross sectional analysis in a Japanese working population with a wide range of occupational. The Jichi medical school cohort study. Journal of Occupational Environment Medicine. 48, $367-373$.

Well, A. Hongan, C. (2016). Occupational stress in hotels. Journal of Hospitality Management 5(2), 200 - 210.

Wong, C.C. and Huang, C.Y. (2014). A Factor cluster approach to understanding Hong Kong hotel employee's symptom management related coping behaviour towards job stress. Asia Pacific Journal of Tourism Research 19(4), $469-491$ 